\title{
COMPARATIVE STUDY OF MICROHABITAT UTILIZATION BY SEEDLINGS OF CANOPY DOMINANT TREE SPECIES IN TROPICAL RAIN FORESTS OF SRI LANKA
}

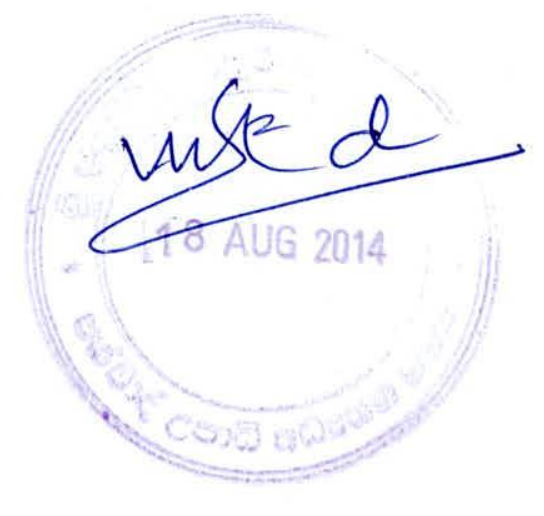

BY

\section{RANASINGHE DISANAYAKALAGE SHERLY SHELTON RANATHUNGA}

Thesis submitted to the University of Sri Jayewardenepura for the award of the Degree of Master of Philosophy in Forestry on Tropical Forest Ecology. 
"We certify that the candidate has incorporated all corrections, additions and amendments recommended by the examiners".

Internal Supervisor

Signature:

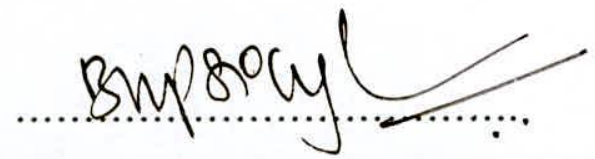

Prof. B.M.P Singhakumara, D.Phil (Oxon)

Professor of Forestry \& Environmental Science,

Department of Forestry and Environmental Science,

University of Sri Jayewardenepura,

Gangodawila, Nugegoda,

Sri Lanka.

Date: .....15 th Angunt 2014

External supervisor

Signature:

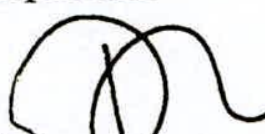

Prof. P.M.S Ashton

Professor of Silviculture and Forest Ecology,

School of Forestry and Environmental Studies,

"Yale University,

360, Prospect Street,

New Haven, CT 06511,

USA.

Date: ......15..................2014 


\section{DECLARATION}

The work describe in this thesis was carried out by me under supervision of Prof. B.M.P Singhakumara and Prof. P.M.S. Ashton and a report on this has not been submitted in whole or in part to any University for another degree.

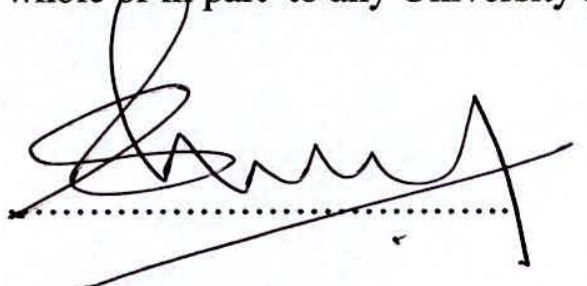

R.D.S.S. Ranathunga

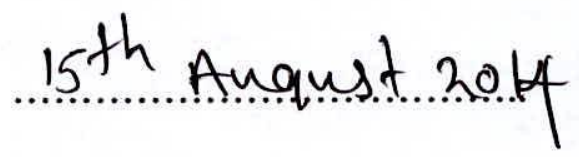

Date

B.Sc. Special (Forestry and Environmental Science) 
We certify that the above statement made by the candidate is true and this thesis is suitable for submission to the university for the purpose of evaluation.

Internal supervisor

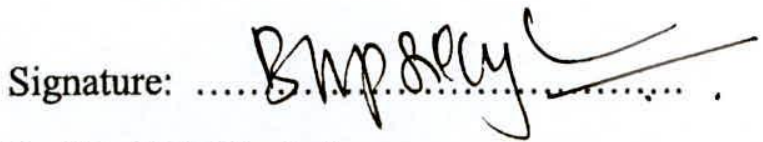

Prof. B.M.P Singhakumara,

Professor of Forestry \& Environmental Science,

Department of Forestry and Environmental Science,

University of Sri Jayewardenepura,

Gangodawila, Nugegoda,

Sri Lanka.

Date: 13 Sept 2013

External supervisor

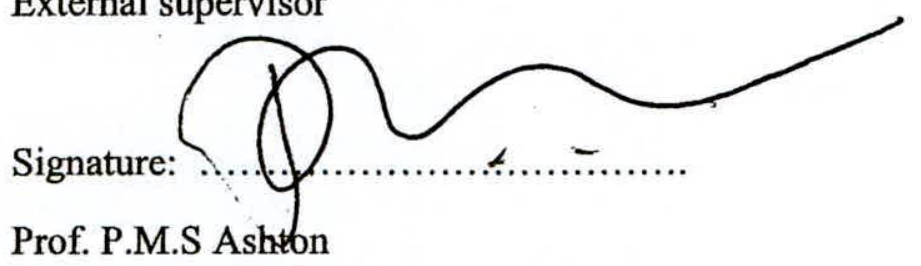

Professor of Silviculture and Forest Ecology,

School of Forestry and Environmental Studies,

"Yale University,

360 , prospect Street,

New Haven, CT 06511,

USA. AnguSt $20^{2} 2013$ 


\section{TABLE OF CONTENTS}

TABLE OF CONTENTS

LIST OF TABLES iv

LIST OF FIGURES vii

LIST OF PLATES $\quad x$

ACKNOWLEDGEMENT $\quad x i$

ABBREVIATIONS xii

DEDICATION X xiii

ABSTRACT

CHAPTER 1: INTRODUCTION 01

$\begin{array}{lll}1.1 & \text { General Introduction } & 02\end{array}$

CHAPTER 02: LITERATURE REVIEW

Micro-site variation in light availability, seedling growth, seedling mortality $\quad 10$ and herbivory in tropical lowland rain forests

$2.1 \quad$ Tree fall gaps in tropical forest 11

2.1.1 Gap formation and gap characteristics 11

2.1.2 Gaps maintain species diversity in forests $\quad 12$

$\begin{array}{ll}2.2 & \text { Light environments in tropical forests } \\ & 12\end{array}$

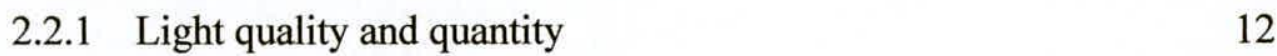

2.2.2 Whole-plant light requirements 13

2.2.3 Light environments and seedling growth 14

2.3 Height increment of seedlings indicates competition for light 16

2.4 Interactions among species distribution and topographic gradients $\quad 17$

$\begin{array}{ll}2.5 & \text { Seedling mortality } \\ & 18\end{array}$

2.5.1 Reasons for seedling mortality in tropical forests 18

2.5.2 Drought effects to seedling mortality 20

2.5.3 Seedling mortality in different topographic positions 21

$\begin{array}{lll}2.6 & & 22\end{array}$

2.6.3 The interaction of seedling community with herbivores 22

2.6.2 The effects of the light environment on herbivory 23

2.6.1 Herbivory along a forest elevation gradient 25

CHAPTER 03: LITERATURE REVIEW

Foliar morphological and physiological plasticity along a natural light 26 gradient

$\begin{array}{lll}3.1 & \text { Introduction } & 27\end{array}$

3.1.1 Sun and shade leaves $\quad 28$

3.2 Leaf morphological variations in different environments 29 
3.2.1 Leaf size 29

3.2.2 Leaf length to leaf width ratio 31

3.2.3 Petiole length and petiole diameter 32

3.2.4 Length of drip-tip 33

3.2.5 Plant branching and branching patterns 33

3.3 Specific leaf area 35

3.4 Specific leaf weight 37

3.5 Leaf dry matter content 38

3.6 Influence of light level and elevation to stomata 39

3.7 Leaf Chlorophyll concentration 42

CHAPTER 04: STUDY OBJECTIVE AND HYPOTHESIS

4.1 Study objective and hypothesis 46

4.1.1 Study objective 46

4.1.2 Hypothesis 46

4.1.3 Overarching Hypotheses 46

$\begin{array}{lll}4.2 & \text { Study sites } & 47\end{array}$

4.3 Study species $\quad 50$

CHAPTER 05: METHODS AND MATERIALS 54

5.1 Experimental design 55

5.1.2 Selecting gaps and understory sites for the study 55

5.1.1 Seedling planting and establishment 55

5.2 Seedling growth and mortality measurements 56

5.2.1 Above-ground measurements $\quad 56$

5.2.2 Seedling mortality 56

5.3 Leaf herbivory measurement 56

5.4 Measurement of leaf functional traits 57

5.4.1 Leaf area, leaf length, leaf width, petiole length and length of 57

5.4.2 Leaf weight measurement $\quad 58$

5.5 Leaf anatomical measurements $\quad 59$

$\begin{array}{ll}5.6 & \text { Spectro- Photometric measurement }\end{array}$

5.7 Statistical interference 61

CHAPTER 06: RESULTS - GROWTH AND MORTALITY 62

6.1 Growth measurements 63

6.1.1 Annual height increment 63

6.1.2 Root collar diameter increment $\quad 69$

$\begin{array}{lll}\text { 6.1.3 Leaf increment } & 74\end{array}$

6.1.4 Branch increment $\quad 77$

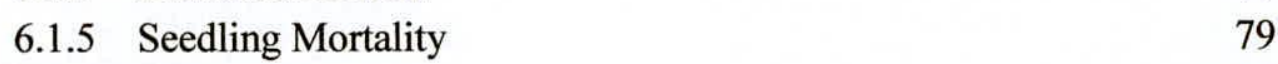

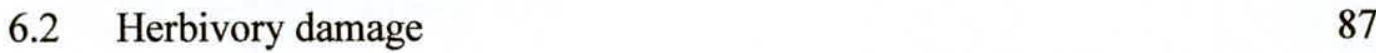


CHAPTER 7: RESULTS - LEAF MORPHOLOGY 92

7.1 Leaf morphology measurements 93

$\begin{array}{lll}\text { 7.1.1 Leaf area } & 93\end{array}$

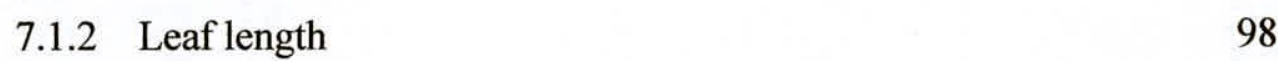

$\begin{array}{ll}\text { 7.1.3 Leaf width } & 102\end{array}$

$\begin{array}{lll}7.1 .4 & \text { Petiole length } & 106\end{array}$

7.1.5 Length of drip-tip 110

7.2 Derived morphological parameters 114

$\begin{array}{ll}\text { 7.2.1 Leaf shape index } & 114\end{array}$

$\begin{array}{lll}7.2 .2 & \text { Specific leaf area } & 119\end{array}$

$\begin{array}{lll}7.2 .3 & \text { Specific leaf weight } & 123\end{array}$

$\begin{array}{ll}\text { 7.2.4 Leaf dry matter content } & 127\end{array}$

$\begin{array}{ll}\text { 7.2.5 Leaf water content } & 131\end{array}$

CHAPTER 8: RESULTS - LEAF ANATOMY 135

$\begin{array}{lll}8.1 & \text { Stomatal measurements } & 136\end{array}$

$\begin{array}{lll}\text { 8.1.1 Stomatal density } & 136\end{array}$

8.1.2 Stomatal length 140

8.1.3 Stomatal index 144

8.2 Leaf pigment concentration 148

8.2.1 Chlorophyll $a$ concentration $\quad 148$

8.2.2 Chlorophyll $b$ concentration $\quad 152$

8.2.3 Total chlorophyll concentration $\quad 157$

$\begin{array}{ll}\text { 8.2.4 Chlorophyll } a / b \text { ratio } & 162\end{array}$

$\begin{array}{ll}\text { CHAPTER 09: DISCUSSION } & 167\end{array}$

9.1 Introductions 168

9.2 Above ground growth performance and mortality 170

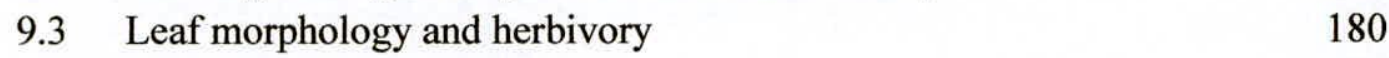

$\begin{array}{ll}9.4 \text { Leaf anatomy and structure } & 192\end{array}$

CHAPTER 10: CONCLUSION 204

10.1 Conclusion 205

10.2 Recommendation to further studies 208

$\begin{array}{lr}\text { REFERENCES } & 209\end{array}$ 


\section{LIST OF TABLES}

Table: 5.1 Summary of study sites in different elevations.

Table: 6.1 Analysis of variance on height increment of seedling in micro-sites at selected elevations.

Table: 6.2 Mean height increment $(\mathrm{cm})$ of species at selected elevations with years after planting.

Table: 6.3 Mean height increment $(\mathrm{cm})$ of species in micro-sites with years after planting.

Table: 6.4 Mean height increment $(\mathrm{cm})$ of species with years after planting.

Table: 6.5 Analysis of variance on root collar diameter increment of seedling data over an 10 years period.

Table: 6.6 Mean root collar diameter increment $(\mathrm{cm})$ of study species at elevations, micro-sites and year after planting

Table: 6.7 Analysis of variance on leaf increment $(\mathrm{cm})$ of seedlings in micro-sites at selected elevations.

Table: 6.8 Mean number of leaves increment on species, micro-sites) and year after planting.

Table: 6.9 Analysis of variance on branch increment of seedlings in micro-sites at selected elevations.

Table: 6.10 Mean branch increment of species in micro-sites with years after planting.

Table: 6.11 Analysis of variance on Arcsine of \% mortality of seedlings in micro-sites at selected elevations.

Table: 6.12 Mean mortality on micro-sites with years after planting.

Table: 6.13 Mean mortality on species in micro-sites with years after planting.

Table: 6.14 Mean mortality on elevations with years after planting.

Table: 6.15 Analysis of variance on IH in micro-sites at selected elevations.

Table: 6.16 Mean of $\mathrm{IH}$ combining species in micro-sites at selected elevations.

Table: 6.17 Summary of regression coefficient among $\mathrm{IH}$ of each species and PPF $\left(\mathrm{molm}^{-2} \mathrm{~s}^{-1}\right)$.

Table: 7.1 Analysis of variance on natural log transformed leaf area $\left(\mathrm{cm}^{2}\right)$ of species in micro-sites at different elevations.

Table: 7.2 Leaf area $\left(\mathrm{cm}^{2}\right)$ combining species combining species in micro-sites at selected elevations. 
Table: 7.3 Summary of regression coefficient among natural log transformed leaf area $\left(\mathrm{cm}^{2}\right)$ of each species and PPF $\left(\mathrm{molm}^{-}\right.$ $\left.{ }^{2} \mathrm{~s}^{-1}\right)$.

Table: 7.4 Analysis of variance on natural log transformed leaf length (cm) of species in micro-sites at different elevations.

Table: 7.5 Leaf length $(\mathrm{cm})$ combining species combining species in micro-sites at selected elevations.

Table: 7.6 Summary of regression coefficient among natural log transformed leaf length $(\mathrm{cm})$ of each species and PPF $\left(\mathrm{molm}^{-}\right.$ $\left.{ }^{2} \mathrm{~S}^{-1}\right)$.

Table: 7.7 Analysis of variance on natural log transformed leaf width (cm) of species in micro-sites at different elevations.

Table: 7.8 Leaf width $(\mathrm{cm})$ combining species combining species in micro-sites at selected elevations.

Table: 7.9 Summary of regression coefficient among natural log transformed leaf width $(\mathrm{cm})$ of each species and PPF $\left(\mathrm{molm}^{-}\right.$ $\left.2 \mathrm{~S}^{-1}\right)$.

Table: 7.10 Analysis of variance on natural log transformed Petiole length $(\mathrm{mm})$ of species in micro-sites at different elevations.

Table: 7.11 Petiole length ( $\mathrm{mm}$ ) combining species combining species in micro-sites at selected elevations.

Table: 7.12 Summary of regression coefficient among natural log transformed Petiole length $(\mathrm{mm})$ of each species and PPF $\left(\mathrm{molm}^{-2} \mathrm{~s}^{-1}\right)$.

Table: 7.13 Analysis of variance on natural log transformed Drip-tip length $(\mathrm{mm})$ of species in micro-sites at different elevations.

Table: 7.14 Drip-tip length ( $\mathrm{mm}$ ) combining species combining species in micro-sites at selected elevations.

Table: 7.15 Analysis of variance on natural log transformed LSI of species in micro-sites at different elevations.

Table: 7.16 LSI combining species combining species in micro-sites at selected elevations.

Table: 7.17 Summary of regression coefficient among natural log transformed LSI of each species and PPF $\left(\mathrm{molm}^{-2} \mathrm{~s}^{-1}\right)$.

Table: 7.18 Analysis of variance on natural log transformed SLA $\left(\mathrm{mm}^{2} \mathrm{mg}^{-1}\right)$ of species in micro-sites at different elevations.

Table: 7.19 SLA $\left(\mathrm{mm}^{2} \mathrm{mg}^{-1}\right)$ combining species combining species in micro-sites at selected elevations.

Table: 7.20 Summary of regression coefficient among natural log transformed SLA $\left(\mathrm{mm}^{2} \mathrm{mg}^{-1}\right)$ of each species and PPF 
$\left(\mathrm{molm}^{-2} \mathrm{~s}^{-1}\right)$.

Table: 7.21 Analysis of variance on natural log transformed SLW

$\left(\mathrm{mgcm}^{-2}\right)$ of species in micro-sites at different elevations.

Table: 7.22 SLW $\left(\mathrm{mgcm}^{-2}\right)$ combining species combining species in micro-sites at selected elevations.

Table: 7.23 Summary of regression coefficient among natural log transformed SLW $\left(\mathrm{mgcm}^{-2}\right)$ of each species and PPF (molm $\left.{ }^{2} \mathrm{~S}^{-1}\right)$.

Table: 7.24 Analysis of variance on natural log transformed LDMC (gg${ }^{1}$ ) of species in micro-sites at different elevations.

Table: 7.25 LDMC $\left(\mathrm{gg}^{-1}\right)$ combining species combining species in micro-sites at selected elevations.

Table: 7.26 Summary of regression coefficient among natural log transformed LDMC $\left(\mathrm{gg}^{-1}\right)$ of each species and PPF $\left(\mathrm{molm}^{-2} \mathrm{~s}^{-}\right.$ 1).

Table: 7.27 Analysis of variance on natural log transformed LWC (\%) of species in micro-sites at different elevations.

Table: 7.28 LWC (\%) combining species combining species in microsites at selected elevations.

Table: 7.29 Summary of regression coefficient among natural log transformed LWC (\%) of each species and PPF $\left(\right.$ molm $\left.^{-2} \mathrm{~s}^{-1}\right)$.

Table: 8.1 Analysis of variance on natural $\log$ transformed SD $\left(\mathrm{mm}^{-2}\right)$ of species in micro-sites at different elevations.

Table: 8.2 SD $\left(\mathrm{mm}^{-2}\right)$ combining species combining species in microsites at selected elevations

Table: 8.3 Summary of regression coefficient among natural log transformed SD $\left(\mathrm{mm}^{-2}\right)$ of each species and PPF $\left(\mathrm{molm}^{-2} \mathrm{~s}^{-1}\right)$.

Table: 8.4 Analysis of variance on natural log transformed SL $(\mu \mathrm{m})$ of species in micro-sites at different elevations.

Table: 8.5 SL $(\mu \mathrm{m})$ combining species combining species in micro-sites at selected elevations.

Table: 8.6 Summary of regression coefficient among natural log transformed SL $(\mu \mathrm{m})$ of each species and PPF $\left(\mathrm{molm}^{-2} \mathrm{~s}^{-1}\right)$.

Table: 8.7 Analysis of variance on natural $\log$ transformed SAI of species in micro-sites at different elevations.

Table: 8.8 SAI combining species combining species in micro-sites at selected elevations.

Table: 8.9 Summary of regression coefficient among natural log transformed SAI of each species and PPF $\left(\mathrm{molm}^{-2} \mathrm{~s}^{-1}\right)$.

Table: 8.10 Analysis of variance on $\mathrm{Chl}_{a}\left(\mu \mathrm{gcm}^{-2}\right)$ of species in micro- 
sites at different elevations.

Table: 8.11 $\mathrm{Chl}_{a}\left(\mu \mathrm{gcm}^{-2}\right)$ combining species combining species in micro-sites at selected elevations.

Table: 8.12 Summary of regression coefficient among $\mathrm{Chl}_{a}\left(\mu \mathrm{gcm}^{-2}\right)$ of each species and PPF (molm $\left.\mathrm{m}^{-2}\right)$.

Table: 8.13 Analysis of variance on $\mathrm{Chl}_{b}\left(\mu \mathrm{gcm}^{-2}\right)$ of species in microsites at different elevations.

Table: 8.14 $\mathrm{Chl}_{b}\left(\mu \mathrm{gcm}^{-2}\right)$ combining species combining species in micro-sites at selected elevations.

Table: 8.15 Summary of regression coefficient among $\mathrm{Chl}_{b}\left(\mu \mathrm{gcm}^{-2}\right)$ of each species and PPF $\left(\mathrm{molm}^{-2} \mathrm{~s}^{-1}\right)$.

Table: 8.16 Analysis of variance on $\mathrm{Chl}_{t o t}\left(\mu \mathrm{gcm}^{-2}\right)$ of species in microsites at different elevations.

Table: 8.17 $\mathrm{Chl}_{\text {tot }}\left(\mu \mathrm{gcm}^{-2}\right)$ combining species combining species in micro-sites at selected elevations.

Table: 8.18 Summary of regression coefficient among $\mathrm{Chl}_{\text {tot }}\left(\mu \mathrm{gcm}^{-2}\right)$ of each species and PPF $\left(\mathrm{molm}^{-2} \mathrm{~s}^{-1}\right)$.

Table: 8.19 Analysis of variance on natural $\log$ transformed $\mathrm{Chl}_{a / b}$ ratio of species in micro-sites at different elevations.

Table: 8.20 $\mathrm{Ch}_{a / b}$ ratio combining species combining species in microsites at selected elevations.

Table: 8.21 Summary of regression coefficient among natural log transformed $\mathrm{Chl}_{a / b}$ ratio of each species and PPF $\left(\mathrm{molm}^{-2} \mathrm{~s}^{-}\right)$. 


\section{LIST OF FIGURES}

Figure: 6.1 Seedling height increments (cm) of canopy dominant tree

seedlings in micro-sites.

Figure: 6.2 Root Collar Diameter $(\mathrm{cm})$ of nine canopy dominant tree seedlings in micro-sites at selected elevations.

Figure: 6.3 Seedling mortality of nine canopy dominant tree seedlings in micro-sites with year after planting.

Figure: 6.4 IH of nine canopy dominant tree seedlings in micro-sites at selected elevations.

Figure: 7.1 Leaf areas $\left(\mathrm{cm}^{2}\right)$ of nine canopy dominant tree seedlings in micro-sites at selected elevations.

Figure: 7.2 Leaf length $(\mathrm{cm})$ of nine canopy dominant tree seedlings in micro-sites at selected elevations.

Figure: 7.3 Leaf width $(\mathrm{cm})$ of nine canopy dominant tree seedlings in micro-sites at selected elevations.

Figure: 7.4 Petiole length ( $\mathrm{mm}$ ) of nine canopy dominant tree seedlings in micro-sites at selected elevations.

Figure: 7.5 Drip tip length $(\mathrm{mm})$ of nine canopy dominant tree seedlings in micro-sites at selected elevations.

Figure: 7.6 LSI of nine canopy dominant tree seedlings in micro-sites at selected elevations.

Figure: 7.7 SLA $\left(\mathrm{mm}^{2} \mathrm{mg}^{-1}\right)$ of nine canopy dominant tree seedlings in micro-sites at selected elevations.

Figure: 7.8 SLW $\left(\mathrm{mgcm}^{-2}\right)$ of nine canopy dominant tree seedlings in micro-sites at selected elevations.

Figure: 7.9 LDMC $\left(\mathrm{gg}^{-1}\right)$ of nine canopy dominant tree seedlings in micro-sites at selected elevations.

Figure: 7.10 LWC (\%) of nine canopy dominant tree seedlings in microsites at selected elevations.

Figure: 8.1 SD $\left(\mathrm{mm}^{-2}\right)$ of of eight canopy dominant tree seedlings in micro-sites at selected elevations.

Figure: 8.2 SL $(\mu \mathrm{m})$ of of eight canopy dominant tree seedlings in microsites at selected elevations.

Figure: 8.3 SAI of of eight canopy dominant tree seedlings in micro-sites at selected elevations.

Figure: 8.4 $\mathrm{Chl}_{a}\left(\mu \mathrm{gcm}^{-2}\right)$ of nine canopy dominant tree seedlings in micro-sites at selected elevations.

Figure: 8.5 $\mathrm{Chl}_{b}\left(\mu \mathrm{gcm}^{-2}\right)$ of nine canopy dominant tree seedlings in micro-sites at selected elevations. 
Figure: 8.6 $\mathrm{Chl}_{\text {tot }}\left(\mu \mathrm{gcm}^{-2}\right)$ of nine canopy dominant tree seedlings in micro-sites at selected elevations.

Figure: 8.7 $\mathrm{Chl}_{a / b}$ ratio of nine canopy dominant tree seedlings in microsites at selected elevations. 


\section{LIST OF PLATES}

Plate 01: Herbivores and herbivory damage in leaves.

Plate 02: Twelve year old S. worthingtonii and M. nagassarium seedling in understory.

Plate 03: Gap site and adjacent understory site at ridge topography

Plate 04: Canopy gap formation and soil disturbances

Plate 05: Stomata present in Syzygium rubicundum (a) and

Dipterocarpus zeylanicus(b)leaf impression 


\section{ACKNOWLEDGEMENTS}

I am greatly indebted to my supervisors, Prof. B.M.P. Singhakumara, Chair Professor Department of Forestry and Environmental Science, University of Sri Jayewardenepura and P.M.S. Ashton, Professor of Silviculture, School of Forestry and Environmental Studies, Yale University, USA, for their invaluable guidance, advice and kind encouragement given to me throughout this project. I duly appreciate their contribution so willingly given towards the final output in spite of their heavy workload.

I wish to thank Prof. H.S. Amarasekara former Head/ Department of Forestry and Environmental Science and Prof. (Mrs.) N. Bandara present Head/ Department of Forestry and Environmental Science, for allowing me to use the facilities of the department to carry out this project.

I wish to extend my thanks to Mr. P. Dias, Senior Lecturer, Department of Statistics and Computer Science and Dr. S.M.C.U.P Subasinghe Department of Forestry and Environmental Science in the University of Sri Jayewardenepura, for their support in statistical analyse. I also gratefully acknowledge Dr. (Mr.) E.P.S.K. Ediriweera, Dr. (Ms.) H.K. Gamage, and all academic staff, Department of Forestry and Environmental Science for assisting me in numerous ways during my study period.

I thank Prof. (Mrs.) Salim, Head/ Botany, Dr. Nissanka, Head/Zoology and their respective academic/ non academic staff for allowing me to carry out leaf anatomical and Chlorophyll analysis. I would like to thank Mr. I.D. Wijesingha, and Mr. S. Wettasingha, technical officers, Asoka Nishantha, Ramanika Botheju and all other non academic staff of the Department of Forestry and Environmental Science who provided friendly and conducive environment in the work place throughout the study period.

I wish to mention the assistance I received from Mr. Keerthirathna, W. Somarathna and other villagers in Kudawa, Sinharaja for facilitating the collection of field data and giving accommodation. Finally, my deepest gratitude and sincere appreciation is extended to my mother and Sepalika for their extreme patience and tolerance during the study period. 


\section{ABBREVIATIONS}

\begin{tabular}{|c|c|}
\hline Chl & Chlorophyll \\
\hline $\mathrm{Chl}_{a}$ & Chlorophyll $a$ \\
\hline $\mathrm{Chl}_{b}$ & Chlorophyll $b$ \\
\hline Chla/b & Chlorophyll $a / b$ \\
\hline $\mathrm{Chl}_{\text {tot }}$ & Total Chlorophyll \\
\hline $\mathrm{cm}$ & Centimeter \\
\hline DL & Length of drip-tip \\
\hline $\mathrm{gg}^{-1}$ & Grams per gram \\
\hline $\mathrm{IH}$ & Index of herbivory \\
\hline LA & Leaf area \\
\hline LDMC & Leaf dry matter content \\
\hline LL & Leaf length \\
\hline $\ln$ & Natural log \\
\hline LSI & Leaf shape Index \\
\hline LW & Leaf width \\
\hline LWC & Leaf water content \\
\hline $\mathrm{mgcm}^{-2}$ & Milligrams per square centimeter \\
\hline molm $^{-2} \mathrm{~s}^{-1}$ & Moles per square meter per second \\
\hline PL & Petiole length \\
\hline PPF & Photosynthetic photon flux \\
\hline $\mathrm{RCD}$ & Root collar diameter \\
\hline SAI & Stomatal area index \\
\hline SD & Stomatal densities \\
\hline SL & Stomatal lengths \\
\hline SLA & Specific leaf areas \\
\hline SLW & Specific leaf weight \\
\hline$\mu \mathrm{m}$ & Micrometer \\
\hline D. zeylanicus & Dipterocarpus zeylanicus \\
\hline M. ferrea & Mesua ferrea \\
\hline M. nagassarium & Mesua nagassarium \\
\hline S. disticha & Shorea disticha \\
\hline S. megistophylla & Shorea megistophylla \\
\hline S. trapezifolia & Shorea trapezifolia \\
\hline S. worthingtonii & Shorea worthingtonii \\
\hline S. makul & Syzygium makul \\
\hline S. rubicundum & Syzygium rubicundum \\
\hline
\end{tabular}




\section{DEDICATION}

To my parents, and loving wife whose enthusiastic encouragement made me to be successful in higher education 


\title{
COMPARATIVE STUDY OF MICROHABITAT UTILIZATION BY SEEDLINGS OF CANOPY DOMINANT TREE SPECIES IN TROPICAL RAIN FORESTS OF SRI LANKA
}

\section{R.D.S.S Ranathunga}

\begin{abstract}
Deforestation and forest degradation are more severe in the tropics that have serious consequences for species, tropical forest ecosystem services and people who depend on forests for their livelihoods. Therefore, knowledge on germination and seedling establishment is important for understanding such community processes as plant recruitment and succession, which is useful for the reforestation, and restoration of degraded forest areas. This study focused to identify variation of seedling leaf anatomy, leaf morphology, seedling growth and mortality along a gradient in light availability ranging from forest understories to small canopy gaps and elevation ranging from low elevation to high elevation in tropical rain forests of Sri Lanka.

The study was carried out at three different elevations in the wet evergreen mixed Dipterocarp rainforest of southwest Sri Lanka. The selected sites were Waga Forest Reserve $\left(\left(6^{0} .55^{\prime} \mathrm{N}, 80^{0} .10^{\prime} \mathrm{E}: 125 \pm 50 \mathrm{~m}\right.\right.$ asl $)$, Sinharaja World Heritage Site $\left(6^{0} .45^{\prime} \mathrm{N}\right.$, $80^{\circ} .30^{\prime} \mathrm{E}: 580 \pm 250 \mathrm{~m}$ asl $)$ and Eastern region of Sinharaja $\left(6^{0} .40^{\prime} \mathrm{N}, 80^{\circ} .40^{\prime} \mathrm{E}: 1200 \pm\right.$ $200 \mathrm{~m}$ asl). For this study, four Shorea species, one Dipterocarpus species, two Syzygium species and two Mesua species were selected. Experiments were designed to investigate competitive outcomes of these species in different light (canopy gap and understory) and elevations (low elevation, valley, mid-slope, ridge and high elevation). The experiment comprised 5184 seedlings of nine species $(16$ seedlings $\times 9$ species per plot $\times 2$ plots per site $\times 14$ sites)
\end{abstract}


To find out the competitive growth of the selected nine species along the light and elevation gradient, seedling height from the top of the apical shoot to the ground, root collar diameter, number of leaves and branches were measured every year. Six leaf extractions of each species in micro-sites at each elevation were prepared to determine area base Chlorophyll $a, b, a / b$ ratio and total Chlorophyll using a spectrophotometric method. One hundred and eight leaf surface impressions were taken from each species in micro-sites at each elevation to analyze stomatal density and aperture length. Leaf herbivory damage and proportion of damage leaves were measured in all plots that represent the elevation gradient. Three thousand five hundred and twenty five leaves from nine species in micro-sites at all elevation were sampled and leaf morphological parameters were measured. Specific leaf area, specific leaf mass, leaf shape index, leaf dry matter content and leaf water content were derived and analyzed.

Shorea trapezifolia and S. rubicundum can be regarded as the more light demanding species, competitively superior as evidenced by their height increment, root collar diameter increment, leaves and branch increment and their morphological adjustment. On other hand Mesua ferrea and S. worthingtonii can be considered as more shade tolerant species and with less competitive ability as compared to other species because of their slow growth rate and high survival under low light availability. Results revealed that leaf area, leaf length, leaf width, drip tip length and petiole length of all species in canopy gaps had higher values than the respective species in the understory conditions. Shorea trapezifolia, D. zeylanicus and S. rubicundum in the canopy gaps had the highest specific leaf area. The slow growing $M$. ferrea, M. nagassarium and S. worthingtonii in the canopy gaps showed the highest leaf dry matter content and the lowest leaf water content. It was demonstrated that $S$. makul and $S$. rubicundum had the highest stomatal 
density and regarded as drought intolerant, while $S$. disticha, S. megistophylla and $S$. worthingtonii in the gaps recorded the lowest stomatal density as an adaptation to drought or water deficient conditions.

Comparing the gaps Dipterocarpus zeylanicus, M. ferrea, S. trapezifolia and $S$. worthingtonii in the gap centers recorded highest Chlorophyll $a$ concentration, while, $D$. zeylanicus, M. ferrea, S. disticha and S. megistophylla had the highest Chlorophyll $b$ concentration. It revealed that the gap leaves of non-Dipterocarp species tended to have a higher Chlorophyll content per unit leaf area than understory leaves. However, the opposite trends were reported for Dipterocarp species.

This study contributes to our understanding of canopy dominant tree seedling growth response and leaf morphological and stomatal variation to the influence of light and elevation. This understanding will help to identify suitable species to plant under different light conditions and different elevations for the purpose of the development of regeneration methods for the management of tropical wet forests. In addition to that, the study facilitated the ability to rank shade tolerance and drought tolerance of each study species. Further work is necessary to understand physiological performance of these species under field conditions. 